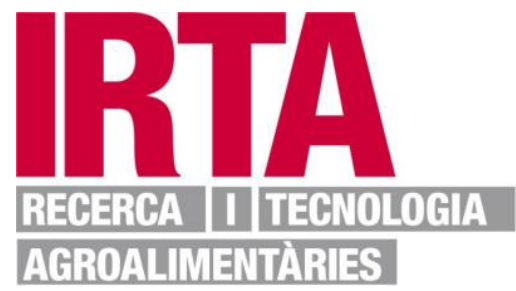

This is a post-peer-review, pre-copyedit version of an article published in Waste and Biomass Valorization. The final authenticated version is available online at: https://doi.org/10.1007/s12649-020-01145-8

Document downloaded from:

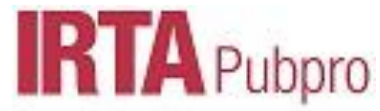

Open dgital archive 


\title{
Brewers' spent yeast and grain as second-generation feedstuff for aquaculture feed
}

${ }^{1}$ AZTI, Bizkaia, Spain

${ }^{2}$ IRTA, Tarragona, Spain

${ }^{3}$ CIC BIOGUNE, Bizkaia, Spain

*Corresponding author: E-mail: dsanmartin@azti.es; Tel.: +34 667174 315; Fax: +34 946572555

\begin{abstract}
Aquafeeds are formulated to contain all the essential nutrients that fishes need to keep healthy. They are highly dependent on marine ingredients: fish meal and oil. Hence, alternative ingredients which successfully replace these marine ingredients are required to result in sustainable and economical feeds. In this context, brewers' spent grain and yeast arise as alternative potential ingredients for aquafeed due their availability and nutritional content. However, reducing aquaculture's dependence on marine resources depends not only on developing alternative ingredients but also on improving their feed efficiencies.
\end{abstract}

In this context, Life Brewery project (LIFE16ENV/ES/000160) proposes an enzymatical hydrolysis step prior to the stabilization process to improve the digestibility of brewers' by-products and, therefore, increases the assimilation of nutrients by fishes. Hence, optimum hydrolysis conditions for both brewers' spent grain and yeast have been defined by comparing different enzymes combination and hydrolysis conditions at laboratory scale. Afterwards, selected enzymes and conditions have been validated at industrial scale. Finally, the digestibility of different experimental diets containing both hydrolysed and un-hydrolysed ingredients from brewers' waste has been determined with positive results.

Based on obtained results, it can be concluded that both hydrolysed and un-hydrolysed brewers' spent grain and yeast are suitable as alternative ingredients which successfully replace marine ingredients. Nevertheless, hydrolysis step improves ingredients efficiency and involves higher digestibility than un-hydrolysed ingredients.

\section{Graphical abstract}

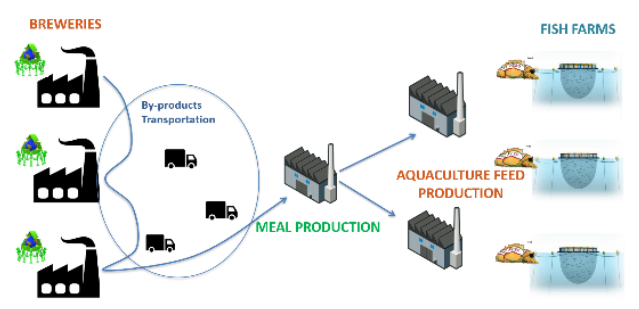

Keywords: Brewers' by-products; Valorisation; Hydrolysis; Alternative ingredients; Sustainability; Circular economy.

\section{Introduction}

Aquaculture sector continues to grow faster than other major food production sectors. The average annual growth rate during the period 2001-2016 was 5.8 percent [1]. In this context, aquafeeds are specially formulated to contain all the essential nutrients that farmed fishes need to keep healthy. They are highly dependent on marine ingredients: specially fish meal (FM) and fish oil (FO). According to IFFO, approximately $69 \%$ of FM and $75 \%$ of FO are utilized in aquaculture production [2]. However, the global fish meal production remains stable over the years or it does not grow at the same rate as demand, with small oscillations due to natural phenomenon such as El Niño phenomenon [1]. Consequently, an increased demand of marine origin ingredients coupled with the stagnation of the recent global fish meal production makes necessary to develop alternative ingredients which successfully replace these marine components with non-traditional sources.

Moreover, Samuel-Fitwi et al. [3] demonstrated that replacing FM by other alternative ingredients, such as soybean or rapeseed, involves less environmental impact per tonne of aqua-feed in both Acidification potential (AP); Global Warming potential (GWP); Eutrophication potential (EP) or Land competition (LC) than fish meal based standard aquafeed. Thus, in case of the GWP, the fish meal standard trout feed has an impact of $1,797 \mathrm{~kg} \mathrm{CO}_{2}$ equivalent per ton while the soybean meal and rapeseed meal based aquafeeds has $1,019.65$ and $1,037.13 \mathrm{~kg} \mathrm{CO}_{2}$, respectively. Consequently, alternative ingredients are also required to result in sustainable feeds.

Within this framework, brewers' by-products arise high potential to be reuse as an alternative raw material for aquafeed due to their availability and their nutritional value. In this sense, European Union (EU) is the $2^{\text {nd }}$ largest beer producer in the world, ahead of USA, Brazil and Russia. According to Eurostat, over 40 billion litres of beer were produced in the European Union (EU) in 2018 [4]. The largest volume of solid by-products produced by breweries are brewers' spent 
grains (BSG) (80\% of total solid by-products), followed by brewers' spent yeast (BSY) (10 \%). So, given EU beer production in 2018, about 7 million tons of BSG (14-20 kg per Hl of beer [5, 6]) and 0.9 million tons of BSY $(2.0-4.0 \mathrm{~kg}$ per $\mathrm{Hl}$ of beer [7-8]) were generated. BSY and BSG are often conventional reused as animal feed and, in some cases, bioethanol production or landfill refuge $[9,10]$. This implies the loss of a valuable product. In addition, the use of these by-products as a direct supply for animal feed without any treatment depends on many factors which can limit significantly their feasibility and, in many cases, can make it unsustainable. The high moisture content together with its high microbial load and the high temperature at which they are generated makes their useful life not more than 48 hours [11, 12].

Regarding to the nutritional value of brewers' by-products, the chemical composition of BSG is characterized by a highwater content (75-80\%) and a high protein content (18-35.4\%, w/w). Their essential amino acids represent approximately $30 \%$ of its total protein content. Lysine accounts for $14.3 \%$ of the total protein content. Other amino acids in significant quantity are leucine, phenylalanine, isoleucine, threonine and tryptophan. Moreover, the presence of several polysaccharides that are constituents of BSG, such as $\beta$-glucans and phenolic compounds, have potential health benefits [7]. In the case of BSY, its chemical composition is characterized by a high-water content (85-90\%) and the presence of carbohydrates, proteins, free amino acids, ash, vitamins and fatty acids. The main important amino acids of BSY are leucine, lysine, tyrosine, arginine, cysteine, histidine, isoleucine, methionine, phenylalanine, threonine, tryptophan and valine. Thus, BSY is an excellent source of high-quality protein. In addition, BSY cell wall contains $\beta$-glucans $(8 \%$, w/w dry weight) and the external layer is formed by mannoproteins. These two compounds have immunomodulatory, antimutagenic and anticarcinogenic activities [7]. Therefore, the nutritional value of BSG and BSY arises high potential to be alternatives ingredient to reduce the high dependence on marine resources of aquafeeds.

However, reducing aquaculture's dependence on marine resources depends not only on developing alternative ingredients but also on improving their feed efficiencies. Thus, proteins of animal origin are considered nutritionally superior to plant origin ones because they have a better proportion of essential amino acids and do not contain anti nutritionals [13, 14]. Moreover, the suitable level of substitution of FM and FO by these new alternative ingredients depends on the target species $[15,16]$. Therefore, increasing the digestibility of these alternative ingredients will increase the assimilation of nutrients by fishes and, thus, the viability of their inclusion on aquafeeds. In this sense, hydrolysis of ingredients arises enormous potential to improve their physical and biochemical properties, leading to a better intestinal absorption [15, 17 , 18]. The hydrolysis of a protein is the reaction which breaks the peptide bonds of the proteins to obtain peptides and free amino acids of different molecular weights [19]. This process must be always adapted to the characteristics of both the initial product to be hydrolysed and the final product to be obtained. In the case of the production of protein hydrolysates from animal by-products which are rich in keratin chemical hydrolysis in acid medium is normally used. While in the other case of animal by-products and by-products such as soybeans, cereals or yeast enzymatic hydrolysis is normally used [20].

Finally, obtained hydrolysates are characterized by their high moisture content which makes them rapidly biodegradable due to the microbial activity $[11,12]$. Thus, their stabilization by applying a drying process is of utmost importance. However, traditional drying processes (rotary drum, fluidized bed, etc.) are energy intensive processes and, subsequently, most of them economically unfeasible at industrial level. Hence, a low energy consumption drying process is necessary to guaranty the profitability of the development of brewers' by-products-based ingredients.

This study is focus on BSG and BY as alternative ingredients for aquafeed which successfully replace marine components. Specifically, the objective is to determine the optimum hydrolysis process by comparing different enzymes combinations and hydrolysis conditions, to develop an efficient and sustainable drying process and to assess the increased digestibility of hydrolysed ingredients with respect to non-hydrolysed in a feed efficiency growth trial with fishes.

\section{Material and methods}

\subsection{Analytical methods}

\subsubsection{Characterization of hydrolysates for hydrolysis kinetic studio}

The analytical method for determining the protein content during the hydrolysis kinetic studio was Nitrogen Determination by the Kjeldahl Method [21].

The analytical method for determining the molecular profile distribution was Sodium Dodecyl Sulphate Polyacrylamide Gel Electrophoresis (SDS-PAGE). Thus, in dry and semi-dry samples, equal amounts of $0.5 \mathrm{~g}$ of each sample were collected. After collection, a soft extraction was performed using ACN: $\mathrm{H}_{2} \mathrm{O}$ [1:1] with $0.1 \%$ TFA. Extracted samples were loaded in SDS-PAGE (12\% acrylamide, $1 \mathrm{~mm}$ width, 10 lanes) a left running during 1.5 hours at 125 volts. In the case of liquid samples, 100 ul were collected, and loaded in each corresponding SAS-PAGE. After running, samples gels were fixed and stained with coomasie blue stain overnight, and finally, destained and stored with water at $4^{\circ} \mathrm{C}$. All process was performed following the Laemmli standardized methodology [22]

The analytical method for determining the hydrolysis degree was High Performance Liquid Chromatography (HPLC) [23]. 
The analytical methods for the characterization of the final ingredients of brewers' by-products-based meals, the experimental feeds used in the digestibility study and the faeces obtained in the digestibility trial were selected following the official methods of analysis published by AOAC (2000) [24].

- Dry matter (\%), dry at $105^{\circ} \mathrm{C}$ for $16-18 \mathrm{~h}$ and estimated by gravimetry (AOAC method 925.09)

- Crude protein (\%) by Dumas procedure and analysis of Nitrogen (FP-528 LECO, AOAC method 968.06)

- Crude fat (\%) Büchi extraction system (B-811 and AOAC method 920.39)

- Ash (\%), ashing the sample at $550^{\circ} \mathrm{C}$ for $16-18 \mathrm{~h}$ (AOAC method 942.05 )

- Gross energy (cal/g) using an adiabatic calorimeter (DIN 51900)

- Crude fibre (\%) using an Ankon fibre analyser based on filter bag technology (AOAC method 962.09)

- Carbohydrates and Starch (\%) Enzymatic method (AOAC method 996.11)

- Phosphorus (\%) Molibdovanadate spectrophotometric method (AOAC method 965.17)

- Vitamin B2 (ppm) HPLC followed by UV detection at $445 \mathrm{~nm}$

- Beta-glucan (g/100 g DM) using a kit Megazyme (Megazyme Int, Ireland) following the method of McCleary $\&$ Codd [25].

- Total amino acids content (\%) Pre-derivatization with o-phthalaldehydet3-mercapto propionic acid (OPA/MPA) and 9-fluorenyl-methylchloroformate (FMOC) and HPLC separation by DAD/FL detection [26].

- Yttrium was analysed by inductively coupled plasma mass spectrometry using the method by Garantum-Tjeldsto et al [27].

\subsection{Hydrolysis kinetic studio and effectiveness determination of each hydrolysis scenario}

The methodology for the assessment of the hydrolysis kinetic depends on the brewers' by-product aimed of study.

\subsubsection{Brewers' spent yeast}

The selection of the commercial enzymes was based on the hydrolysis objectives: on the one hand, to hydrolyse the protein with the aim of increasing the digestibility of ingredients in fishes $[15,17,18]$ and, on the other hand, to increase the palatability. In this sense, there are some studies that shown the importance of reducing bitterness in the acceptance of new diets by fishes [28]. Thus, the selected commercial enzymes were:

- Protamex $®$ : the key enzyme activity is provided by serine endo-protease that hydrolyses internal peptide bonds

- Flavourzyme ${ }^{\circledR}$ : the key enzyme activity is provided by exopeptidase that liberates amino acids by hydrolysis of the N-terminal peptide bond.

Within this framework, three different scenarios were studied at laboratory scale: enzymes hydrolysis kinetic and effectiveness when acting alone or when they are combined

- Scenario 1: supply Protamex $\circledR^{\circledR}$ and Flavourzyme® enzymes at the same time

The objective of this scenario was to assess the protease activity of both enzymes at the same time, taking advantage of the improvement of the reduction of bitterness with the Flavourzyme ${ }^{\circledR}$ enzyme.

- Scenario 2: supply only Protamex® enzyme

The objective of this scenario was to assess the protease activity of the Protamex®, without the action of Flavourzyme ${ }^{\circledR}$ for reducing the bitterness of final product.

- Scenario 3: supply only Flavourzyme ${ }^{\circledR}$ enzyme

The objective of this scenario was to assess if the protease activity of Flavourzyme ${ }^{\circledR}$ was high enough compared with the scenario 2 and scenario 3 .

The hydrolysis kinetic of each hydrolysis scenario was studied by analysing the protein content of intermediate hydrolysates at different stages of the hydrolysis process by Kjeldahl method.

The effectiveness of each hydrolysis scenario was assessed by determining the molecular profile distribution of different hydrolysates by SDS-PAGE to assess the hydrolysis degree. With the aim of simulating the production conditions of the final ingredients described in section 2.3, obtained hydrolysates from each hydrolysis scenario was mechanical dewatered to obtain a liquid fraction, which is going to be rejected and discharged, and a semi-solid fraction, which is the objective fraction and which is going to be dried for the determination of protein digestibility in fishes.

\subsubsection{Brewers' spent grain}

The selection of the commercial enzymes was based on the hydrolysis objectives that, in case of BSG, was not only to hydrolyse the protein but also the fibre. There are some studies that shown that fibre is a potential anti-nutritional for fishes [13, 14]. Thus, the selected commercial enzymes were:

- Celluclast $®:$ the key enzyme activity is provided by a selected strain of fungus called Trichoderma resei that hydrolyses cellulose to glucose, cellobiose and larger polymers of glucose.

- Protamex $®$ : the key enzyme activity is provided by serine endo-protease that hydrolyses internal peptide bonds 
Within this framework, three different scenarios were studied at laboratory scale: enzymes hydrolysis kinetic and effectiveness when acting alone, when they are combined and when they are sequenced or supplied at the same time

- Scenario 1: sequenced supply of Celluclast ${ }^{\circledR}$ and Protamex ${ }^{\circledR}$ enzymes.

Celluclast $\AA$ enzymes is supplied firstly and, once this has made the fibre hydrolysis, the Protamex ${ }^{\circledR}$ enzyme is supplied.

The objective of this scenario was to test the increase of the access to protein of Protamex® enzyme after the fiber hydrolysis.

- $\quad$ Scenario 2: supply of Celluclast ${ }^{\circledR}$ and Protamex $®$ enzymes at the same time The objective was to compare the effectiveness regarding scenario 1.

- $\quad$ Scenario 3: supply only Protamex ${ }^{\circledR}$

The objective was to compare the effectiveness of Protamex ${ }^{\circledR}$ enzyme without fiber hydrolysis and regarding scenario 1 and 2 .

The hydrolysis kinetic of each hydrolysis scenario was studied by analysing the protein content of intermediate hydrolysates at different stages of the hydrolysis process by Kjeldahl method.

The effectiveness of each hydrolysis scenario was assessed by determining the molecular profile distribution of different hydrolysates by SDS-PAGE to assess the hydrolysis degree. With the aim of simulating the production conditions of the final ingredients described in section 2.3, obtained hydrolysates from each hydrolysis scenario was mechanical dewatered to obtain the liquid fraction, which is going to be rejected and discharged, and a semi-solid fraction, which is the objective fraction and which is going to be dried for the determination of protein digestibility in fishes.

\subsection{Scaling up of ingredients production}

The methodology for scaling up the ingredient production consisted of a first mechanical dehydration to reduce as much as possible the humidity (less than $60 \%$ ), which involves a low energy demand and, therefore, a reduction of the energy necessary for thermal drying in the second step. The second phase applies a thermal drying to reduce moisture content below $10 \%$.

Mechanical dehydration technologies selection depends on the physical properties of the targeted products. In case of BSG, the selected technology was a filter centrifuge whereas in case of BY the selected technology was a decanter centrifuge:

- Filter centrifuge is based on the principle of gravity and centrifugal force. It puts an object in rotation around a fixed axis and applies a force perpendicular to the axis of spin (outward). The centrifugal force makes denser particles to move outward in the radial direction and less dense particles to the centre. Therefore, in case of BSG, the solid particles are trapped in a separation mesh that can have different pore size due to the centrifugal force and the liquid flows out from the upper side of the separator.

- Decanter centrifuge is based on the principle of separation via buoyancy to separate continuously solid materials from liquids. Considering that a denser particle falls to the bottom, while a less dense particle is suspended above it, a decanter centrifuge increases the rate of settling using continuous rotation to reduce the settling time of the particles.

Thermal drying technology selection depends fundamentally on its efficiency. Thus, flash drying technology was selected as the most appropriate thermal drying technology for drying both BSY and BSG.

- Flash dryer is based on the instant, self-regulating and continuous drying of wet solids. It is a high thermal efficiency technology which combines the effect of turbulence with the high-speed movement of wet solid particles to dry them instantly. The products are broken in the drying chamber (Figure 1) and the surface area of particles increases significantly, and therefore, decreasing the required energy to dry them. Finally, a minimum heating during a short time of residence - fractions of a second - makes it suitable for temperature-sensitive products maintaining the nutritional value and food security [29]. 


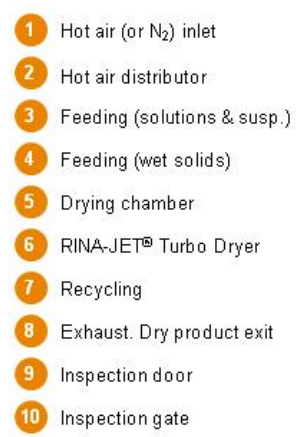

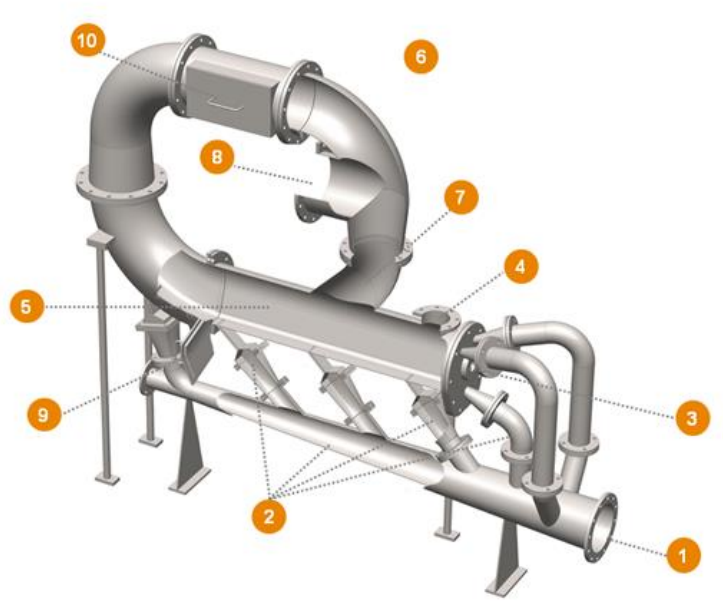

Fig. 1: Structure of the RINA-JET flash dryer technology

The different equipment used in this study for the scaling up of the ingredients production were:

1. Decanter centrifuge "GEA CA 225-00-33”, owned by GEA Westfalia (Barcelona, Spain).

2. Filter centrifuge "RINA 200F 1000 S PI", owned by Riera Nadeu company (Granollers, Spain).

3. Flash dryer "RINA-JET S-1008", owned by the Riera Nadeu company (Granollers; Spain).

\subsection{Determination of protein digestibility in fishes}

The selected fish species was gilthead seabream (Sparus aurata) as a model of Mediterranean aquaculture.

\subsubsection{Experimental diets determination}

A commercial-based diet for gilthead seabream using fish meal (Corpesca Super Prime LT, Chile) was formulated and extruded at IRTA facilities using an extruder (marca y modelo). To this mixture $20 \mathrm{~g} / \mathrm{kg}$ or Yttrium oxide (Sigma, Spain) was added as an inert marker for the evaluation of the apparent digestibility coefficient (ADC).

In addition, four experimental diets were also produced by mixing $700 \mathrm{~g} / \mathrm{kg}$ of the basal mixture and $300 \mathrm{~g} / \mathrm{kg}$ of each test ingredient (BSY and BSG, hydrolysed and unhydrolyzed). The reference diet contained $209 \mathrm{~g} / \mathrm{kg}$ of starch to enable extrusion of the pellets which was hindered due to its high fibre content.

All the diets were formulated to be iso-protein and iso-lipidic and are presented in Tables 1 and 2. The inclusion of spent yeast and spent grain resulted in experimental diets that had 393 to $420 \mathrm{~g} / \mathrm{Kg}$ crude protein, 218 to $224 \mathrm{~g} / \mathrm{Kg}$ crude fat, 17 to $19 \mathrm{MJ} / \mathrm{Kg}$ gross energy, reflecting the similarity among the diets

Table 1: Formula of the experimental diets for protein digestibility determination in Gilthead seabream

\begin{tabular}{cccccc} 
Ingredients & Control & $\begin{array}{c}\text { D-Spent } \\
\text { yeast 30 \% }\end{array}$ & $\begin{array}{c}\text { H-Spent } \\
\text { yeast 30 \% }\end{array}$ & $\begin{array}{c}\text { D- Spent } \\
\text { grain 20 \% }\end{array}$ & $\begin{array}{c}\text { H-Spent } \\
\text { grain 20 \% }\end{array}$ \\
\hline Fish meal 70 LT & 60.00 & 40.00 & 42.00 & 50.00 & 50.00 \\
Wheat starch & 20.95 & 9.45 & 7.45 & 10.00 & 10.00 \\
Spent yeast & - & 30.00 & - & - & - \\
Hydrolyzed spent yeast & - & - & 30.00 & - & - \\
$\quad$ Spent grain & - & - & - & 20.00 & - \\
Hydrolyzed spent grain & - & - & - & - & 20.00 \\
$\quad$ Fish oil & 18.00 & 19.50 & 19.50 & 16.50 & 17.00 \\
Vit \& Min Premix PV01 & 1.05 & 1.05 & 1.05 & 1.05 & 1.05 \\
$\quad$ Yttrium & 0.02 & 0.02 & 0.02 & 0.02 & 0.02 \\
\hline
\end{tabular}

Table 2: Composition of the experimental diets for protein digestibility determination in gilthead seabream

\begin{tabular}{|c|c|c|c|c|c|}
\hline Parameters & Control & $\begin{array}{c}\text { D-Yeast } \\
30 \%\end{array}$ & $\begin{array}{c}\text { H-Yeast } \\
30 \%\end{array}$ & $\begin{array}{c}\text { D- Spent grain } \\
20 \%\end{array}$ & $\begin{array}{c}\text { H-Spent grain } \\
20 \%\end{array}$ \\
\hline Dry matter & 978,30 & $979,20 \quad \pm 2,36$ & 976,60 & 980,50 & 978,10 \\
\hline
\end{tabular}




\begin{tabular}{|c|c|c|c|c|c|c|c|c|c|c|}
\hline (DM, g/Kg) & & & & & & & & & & \\
\hline $\begin{array}{c}\text { Ash } \\
(\mathrm{g} / \mathrm{Kg} \mathrm{DM})\end{array}$ & 98,80 & $\pm 0,98$ & 83,20 & $\pm 0,77$ & 78,70 & $\pm 0,76$ & 93,60 & $\pm 4,24$ & 100,60 & $\pm 1,07$ \\
\hline $\begin{array}{l}\text { Crude protein } \\
\text { (g/Kg DM) }\end{array}$ & 419,80 & $\pm 3,39$ & 413,30 & $\pm 0,16$ & 418,20 & $\pm 2,49$ & 417,70 & $\pm 3,51$ & 392,80 & $\pm 0,70$ \\
\hline $\begin{array}{l}\text { Crude fat } \\
\text { (g/Kg DM) }\end{array}$ & 218,42 & $\pm 3,29$ & 223,94 & $\pm 1,45$ & 234,04 & $\pm 5,71$ & 219,83 & $\pm 2,04$ & 221,40 & $\pm 1,59$ \\
\hline $\begin{array}{c}\text { Carbohydrates } \\
\text { (g/Kg DM) }\end{array}$ & 215,10 & $\pm 8,42$ & 218,50 & $\underset{16,36}{ \pm}$ & 197,00 & $\pm 4,22$ & 130,20 & $\pm 9,07$ & 166,20 & $\pm 11,46$ \\
\hline $\begin{array}{l}\text { Gross energy } \\
(\mathrm{MJ} / \mathrm{Kg} \mathrm{DM})\end{array}$ & 18,65 & $\pm 0,08$ & 18,89 & $\pm 0,19$ & 19,04 & $\pm 0,32$ & 17,25 & $\pm 0,22$ & 17,53 & $\pm 0,23$ \\
\hline
\end{tabular}

\subsubsection{Digestibility trials with fishes}

The protein digestibility trials of obtained ingredients with fishes were carried out at IRTA facilities using recirculation (RAS) systems. The fishes were purchased in a commercial farm (Piscimar, Castellón, Spain), transported by road to IRTA facilities, acclimatized for 15 days and then randomly distributed in fifteen $500 \mathrm{~L}$ tanks with individual faeces sedimentation columns in the outflow of the tanks. Twenty-five fishes with a body weight of $253.01 \pm 27.68 \mathrm{~g}$ were randomly distributed in the tanks connected to the RAS systems and kept at $20^{\circ} \mathrm{C}$ under natural light.

The experimental diets were randomly assigned to the tanks and fed in triplicate. Fish were fed $100 \mathrm{~g}$ of the feeds once daily for 2 weeks before faecal collection. Gilthead seabream faeces were collected in the sedimentation columns for 3 alternate days. Gilthead sea bream were also fed once per day during the collection period and the tanks cleaned to avoid any uneaten feed in the tanks and in the faecal collectors. Faecal samples were freeze dried for $24 \mathrm{~h}$ and stored at $-20^{\circ} \mathrm{C}$ until chemical analyses.

The apparent digestibility coefficients (ADC) of the experimental diets were calculated according to Maynard et al methodology [30]

$\operatorname{ADC}(\%)=100 \times\left(1-\left(\right.\right.$ dietary $\mathrm{Y}_{2} \mathrm{O}_{3}$ level /faeces $\mathrm{Y}_{2} \mathrm{O}_{3}$ level $) \times$ (faeces nutrient or energy level / dietary nutrient or energy level)

The ADC of the test ingredients were estimated according to National Research Council method [31]

$\mathrm{ADC}_{\mathrm{BSG}}(\%)=\mathrm{ADC}_{\text {test }}+\left[\left(\mathrm{ADC}_{\text {test }}-\mathrm{ADC}_{\text {ref }}\right) \times\left(\left(0.8 \times \mathrm{D}_{\text {ref }}\right) /\left(0.2 \times \mathrm{D}_{\text {ing }}\right)\right)\right]$

$\operatorname{ADC}_{\mathrm{BSY}}(\%)=\mathrm{ADC}_{\text {test }}+\left[\left(\mathrm{ADC}_{\text {test }}-\mathrm{ADC}_{\text {ref }}\right) \times\left(\left(0.7 \times \mathrm{D}_{\text {ref }}\right) /\left(0.3 \times \mathrm{D}_{\text {ing }}\right)\right)\right]$

Where $\mathrm{ADC}_{\text {test }}=\mathrm{ADC}(\%)$ of the experimental diet

$\mathrm{ADC}_{\text {ref }}=\mathrm{ADC}(\%)$ of the reference diet

$\mathrm{D}_{\text {ref }}=\mathrm{g} / \mathrm{Kg}$ nutrient (or MJ/Kg gross energy) of the reference diet (DM basis)

$\mathrm{D}_{\text {ing }}=\mathrm{g} / \mathrm{Kg}$ of nutrient (or MJ/Kg gross energy) of the test diet (DM basis)

\section{Results and discussion}

\subsection{Hydrolysis kinetic studio and effectiveness determination of each hydrolysis scenario}

\subsubsection{Spent yeast}

The hydrolysis kinetic studio results show that descripción de cómo se aumenta la proteína en la fase líquida (se solubiliza) y como disminuye en la fase sólida (Figuras)

MIKEL

The results of effectiveness of each hydrolysis scenario by SDS-PAGE (Figure 2) show that, in H3.2 lane (semi-solid fraction), protease activity has been low, with dense high molecular mass bands (above $25 \mathrm{kDa}$ ). On the other hand, H1.2 and H2.2 (semi-solid fractions) look very similar, with apparently higher protease activity, in contrast to H3.2 (semi-solid fraction). In all cases, liquid fractions (H1.1, H2.1 and H3.1 lanes) show very little amount of protein. 


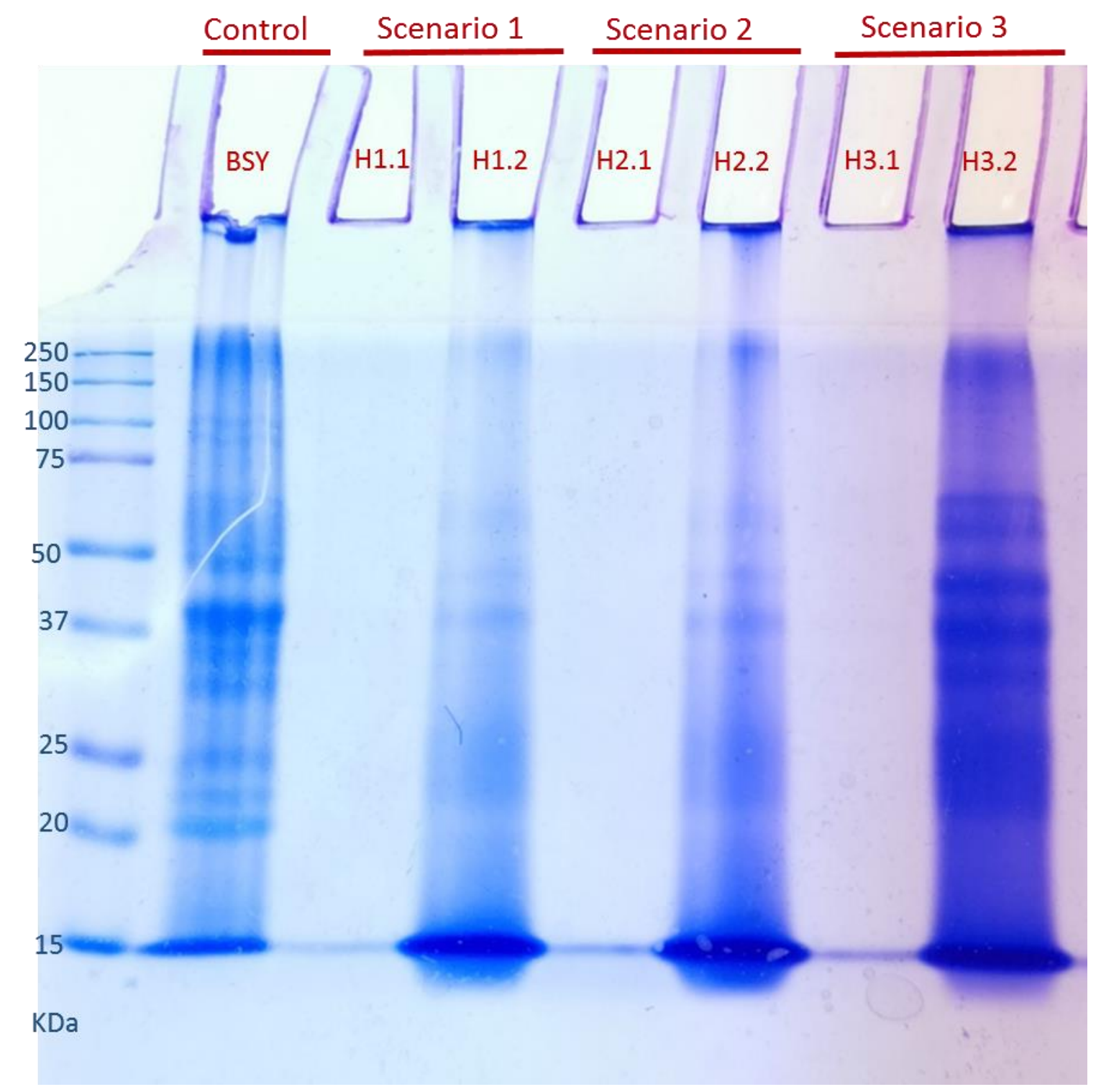

Fig. 2: Molecular profile distribution of different BSY hydrolysis scenarios by SDS-PAGE method

Considering the obtained results, the scenario 1 (supply Protamex ${ }^{\circledR}$ and Flavourzyme ${ }^{\circledR}$ enzymes at the same time) has been selected as the most appropriate for the protein hydrolysis of BSY to produce a new ingredient for aquaculture feed. The scenario 3 (supply only Flavourzyme ${ }^{\circledR}$ enzyme) has been rejected due to the low protease activity. In addition, although the effectiveness of the scenario 2 (supply only Protamex ${ }^{\circledR}$ enzymes) is quite similar to scenario 2 , and therefore the expected protein digestibility improvement in fishes should be similar, the expected reduction in the bitterness related to scenario 1 due to the activity of Flavourzyme ${ }^{\circledR}$ enzymes has been considered of high importance to ensure the viability of this new ingredient for aquaculture feed application.

\subsubsection{Spent grain}

The hydrolysis kinetic studio results show that descripción de cómo se aumenta la proteína en la fase líquida (se solubiliza) y como disminuye en la fase sólida (Figuras)

MIKEL

The results of effectiveness of each hydrolysis scenario by SDS-PAGE (Figure 3), they show that, xxxxx.

\section{CIC-BIOGUNE}

Fig. 3: Molecular profile distribution of different BSG hydrolysis scenarios by SDS-PAGE method 
Considering the obtained results, scenario 1 (sequenced supply of Celluclast ${ }^{\circledR}$ and Protamex ${ }^{\circledR}$ enzymes), scenario 2 (supply of Celluclast ${ }^{\circledR}$ and Protamex ${ }^{\circledR}$ enzymes at the same time) and scenario 3 (supply only Protamex®) are viable for the protein hydrolysis of BSG to produce a new ingredient for aquaculture feed.

However, provided fibre is considered as anti-nutritional parameter for fishes [13,14], the fibre hydrolysis related to the activity of Celluclast ${ }^{\circledR}$ enzymes has been considered of high importance to ensure the viability of this new ingredient for aquaculture feed application. Thus, the scenario 3 has been rejected for this proposal.

Regarding Celluclast ${ }^{\circledR}$ enzyme activity for fibre hydrolysis, this could be inactivated by the Protamex ${ }^{\circledR}$ enzyme activity it they act simultaneously (scenario 2). Thus, the scenario 1 (sequenced supply of Celluclast $®$ and Protamex ${ }^{\circledR}$ enzymes) has been selected as the most appropriate for the hydrolysis of BSG to produce a new ingredient for aquaculture feed because Celluclast ${ }^{\circledR}$ enzyme acts firstly and, once the fibre hydrolysis has been carried out, Protamex ${ }^{\circledR}$ enzyme is supplied, so the inactivation of Celluclast ${ }^{\circledR}$ enzyme by Protamex ${ }^{\circledR}$ enzyme has been avoided. In addition, there is a light tendency to a higher proteolytic activity in the band of $50-150 \mathrm{kDa}$ related to scenario 1.

\subsection{Scaling up of ingredients production}

\subsubsection{Spent yeast}

The scaling up of 2 different ingredients from BSY: hydrolysed (scenario 1) and un-hydrolysed consisted of a first mechanical dehydration to reduce as much as possible the humidity (less than $60 \%$ ) and a second thermal drying to reduce moisture content below $10 \%$. Obtained ingredients have been used in the determination of protein digestibility in fishes in section 3.3.1. The biochemical composition of these ingredients are shown in the Table 3.

Table 3: Brewers' spent yeast-based ingredients nutritional value

\begin{tabular}{|c|c|c|}
\hline Parameter & $\begin{array}{l}\text { Un-hydrolysed } \\
\text { Spent yeast }\end{array}$ & $\begin{array}{l}\text { Hydrolysed } \\
\text { Spent yeast }\end{array}$ \\
\hline Dry matter (\%) & 94.19 & 89.05 \\
\hline Crude protein $(\%)$ & 45.07 & 41.24 \\
\hline Ether extract (\%) & 0.35 & 0.45 \\
\hline $\operatorname{Ash}(\%)$ & 3.99 & 3.87 \\
\hline Gros energy (cal/g) & 4477 & 4238 \\
\hline Crude fibre $(\%)$ & 0.64 & 0.62 \\
\hline Starch $(\%)$ & 20.59 & 20.05 \\
\hline Phosphorus (\%) & 0.91 & 0.87 \\
\hline Vitamin B2 (ppm) & 2.60 & 5.00 \\
\hline Total a.a. content (\%) & 40.60 & 36.63 \\
\hline Aspartic acid & 4.51 & 4.08 \\
\hline Glutamic acid & 5.68 & 5.19 \\
\hline Serine & 2.39 & 2.16 \\
\hline Histidine & 1.14 & 1.02 \\
\hline Glycine & 1.78 & 1.63 \\
\hline Threonine & 2.29 & 2.09 \\
\hline Arginine & 2.37 & 2.12 \\
\hline Alanine & 2.77 & 2.52 \\
\hline Tyrosine & 1.62 & 1.40 \\
\hline Valine & 2.50 & 2.25 \\
\hline Methionine & 0.77 & 0.69 \\
\hline Phenylalanine & 2.17 & 2.00 \\
\hline Isoleucine & 2.21 & 2.02 \\
\hline Leucine & 3.31 & 3.00 \\
\hline Lysine & 2.99 & 2.57 \\
\hline
\end{tabular}




$\begin{array}{lll}\text { Hydroxyproline } & <0.03 & <0.03 \\ \text { Proline } & 2.10 & 1.89\end{array}$

Figure 4, related to the SDS-PAGE analysis of the protein hydrolysis effectiveness of the results at laboratory scale (H1.1 and H1.2) comparing with the industrial scale ones (H1.3, H1.4 and H1.5), shown very similar SDS-PAGE patterns, hence, similar levels of protease activity. The amount of hydrolysis seems the same, with similar composition of remaining high molecular mass bands. This shows that the scaling up of the scenario 1 at semi-industrial scale was performed correctly.

In addition, the stabilization process of the semi-solid fraction (H1.4) obtained by performing the hydrolysis scenario 1 to obtain the dried ingredient (H1.5) show no differences. So, the stabilization process doesn't affect to the protein content and its molecular profile distribution.

Finally, as in Figure 2, liquid fractions (H1.1 and H1.3) show very little amount of protein. This involves that the stabilization process proposed for drying BSY in an efficient way is compatible with the hydrolysis process since the loss of soluble protein in the liquid fraction, which is rejected and discharged, is minimal.

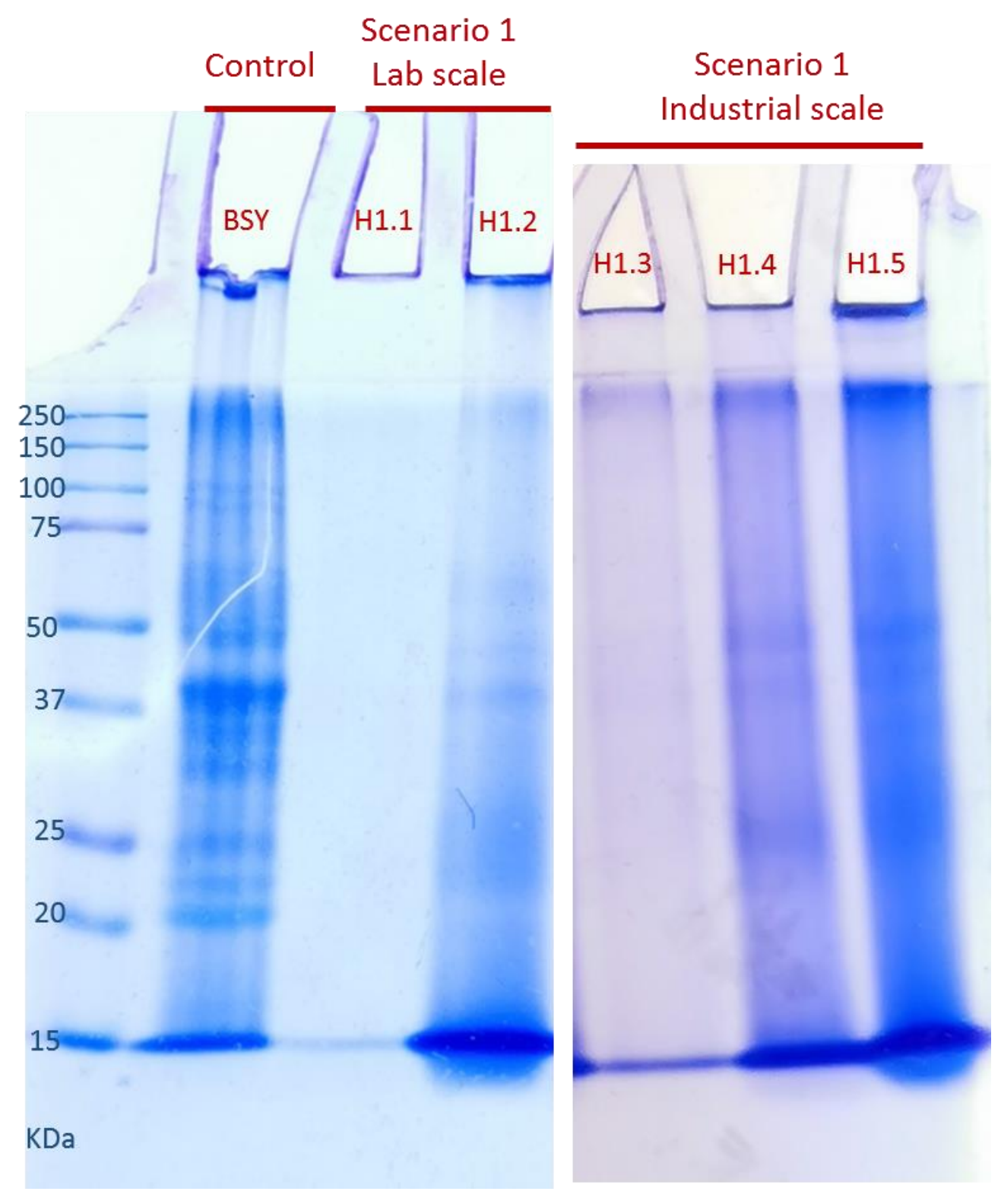

Fig. 4: Molecular profile distribution of the BSY hydrolysis scenario 1 at lab and industrial scale by SDS-PAGE method

Finally, Figure 5 compares two different stabilization process: one based on Spry dryer technology (1) and other based 

between both drying techniques.

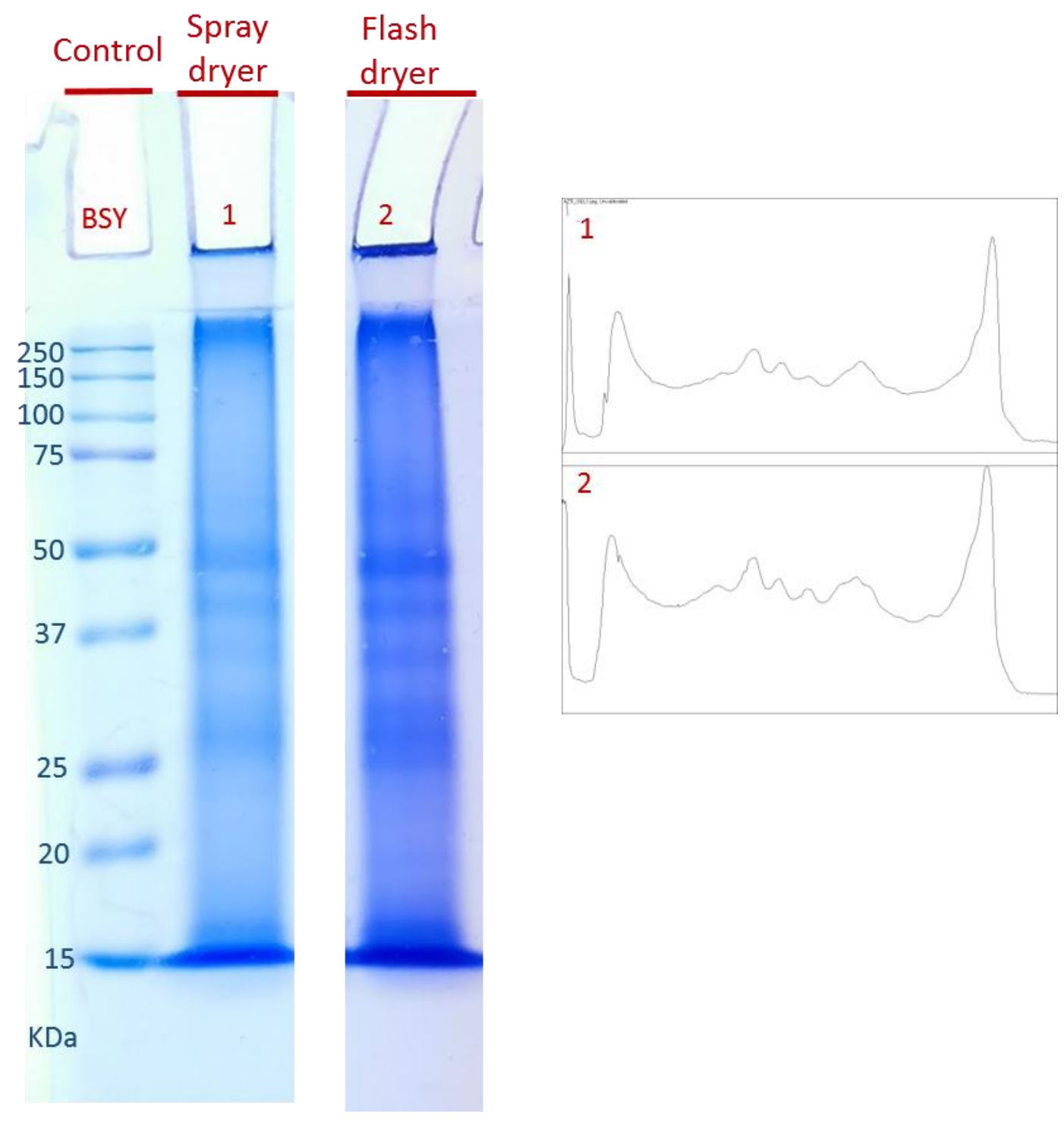

Fig. 5: Molecular profile distribution of un-hydrolysed BSY dried by spray dryer and flash dryer by SDS-PAGE

\subsubsection{Spent grain}

The scaling up of 2 different ingredients from BSG: hydrolysed (scenario 1) and un-hydrolysed consisted of a first mechanical dehydration to reduce as much as possible the humidity (less than $60 \%$ ) and a second thermal drying to reduce moisture content below $10 \%$. Obtained ingredients have been used in the determination of protein digestibility in fishes in section 3.3.2. The biochemical composition of these ingredients are shown in Table 4

Table 4: Brewers' spent grain -based ingredients nutritional value

\begin{tabular}{lll} 
Parameters & $\begin{array}{l}\text { Un-hydrolysed } \\
\text { Spent grain }\end{array}$ & $\begin{array}{l}\text { Hydrolysed } \\
\text { Spent grain }\end{array}$ \\
\hline Dry matter (\%) & 92.00 & 98.11 \\
Crude protein (\%) & 22.73 & 21.38 \\
Ether extract (\%) & 7.75 & 11.46 \\
Ash (\%) & 3.60 & 5.99 \\
Gros energy (cal/g) & 4766 & 4838 \\
Crude fibre (\%) & 17.28 & 16.28 \\
Starch (\%) & 3.59 & 3.43
\end{tabular}




\begin{tabular}{|c|c|c|}
\hline Phosphorus (\%) & 0.49 & 0.34 \\
\hline Vitamin B2 (ppm) & 0.40 & 1.40 \\
\hline Total a.a. content $(\%)$ & 22.51 & 18.67 \\
\hline Aspartic acid & 1.58 & 1.42 \\
\hline Glutamic acid & 4.82 & 3.62 \\
\hline Serine & 1.03 & 0.86 \\
\hline Histidine & 0.60 & 0.55 \\
\hline Glycine & 0.81 & 0.78 \\
\hline Threonine & 0.84 & 0.79 \\
\hline Arginine & 1.18 & 1.05 \\
\hline Alanine & 1.39 & 1.15 \\
\hline Tyrosine & 0.88 & 0.79 \\
\hline Valine & 1.17 & 1.03 \\
\hline Methionine & 0.47 & 0.38 \\
\hline Phenylalanine & 1.33 & 1.11 \\
\hline Isoleucine & 0.94 & 0.79 \\
\hline Leucine & 2.28 & 1.81 \\
\hline Lysine & 0.88 & 0.72 \\
\hline Hydroxyproline & $<0.03$ & 0.03 \\
\hline Proline & 2.31 & 1.79 \\
\hline
\end{tabular}

Figure 6, related to the SDS-PAGE analysis of the protein hydrolysis effectiveness of the results at laboratory scale (lane H1.1 and H1.2) comparing with the industrial scale ones (H1.3, H1.4 and H1.5) shown that a clear hydrolysis has been performed, in comparison to control (BSG). But, at industrial scale (H1.3 to H1.5) the hydrolysis seems to be higher than at laboratory scale (H1.1 and H1.2). H1.2 shows higher intensity bands above $25 \mathrm{kDa}$ than those in H1.4 and H1.5. This is clearly visible by showing the corresponding densitograms. This shows that the scaling up of the scenario 1 at semiindustrial scale was performed correctly.

In addition, the stabilization process of the semi-solid fraction (H1.4) obtained by performing the hydrolysis scenario 1 to obtain the dried ingredient (H1.5) show no differences. So, the stabilization process doesn't affect to the protein content and its molecular profile distribution.

Finally, as in Figure 3, liquid fractions (H1.1 and H1.3) show very little amount of protein. This involves that the of soluble protein in the liquid fraction, which is rejected and discharged, is minimal. 


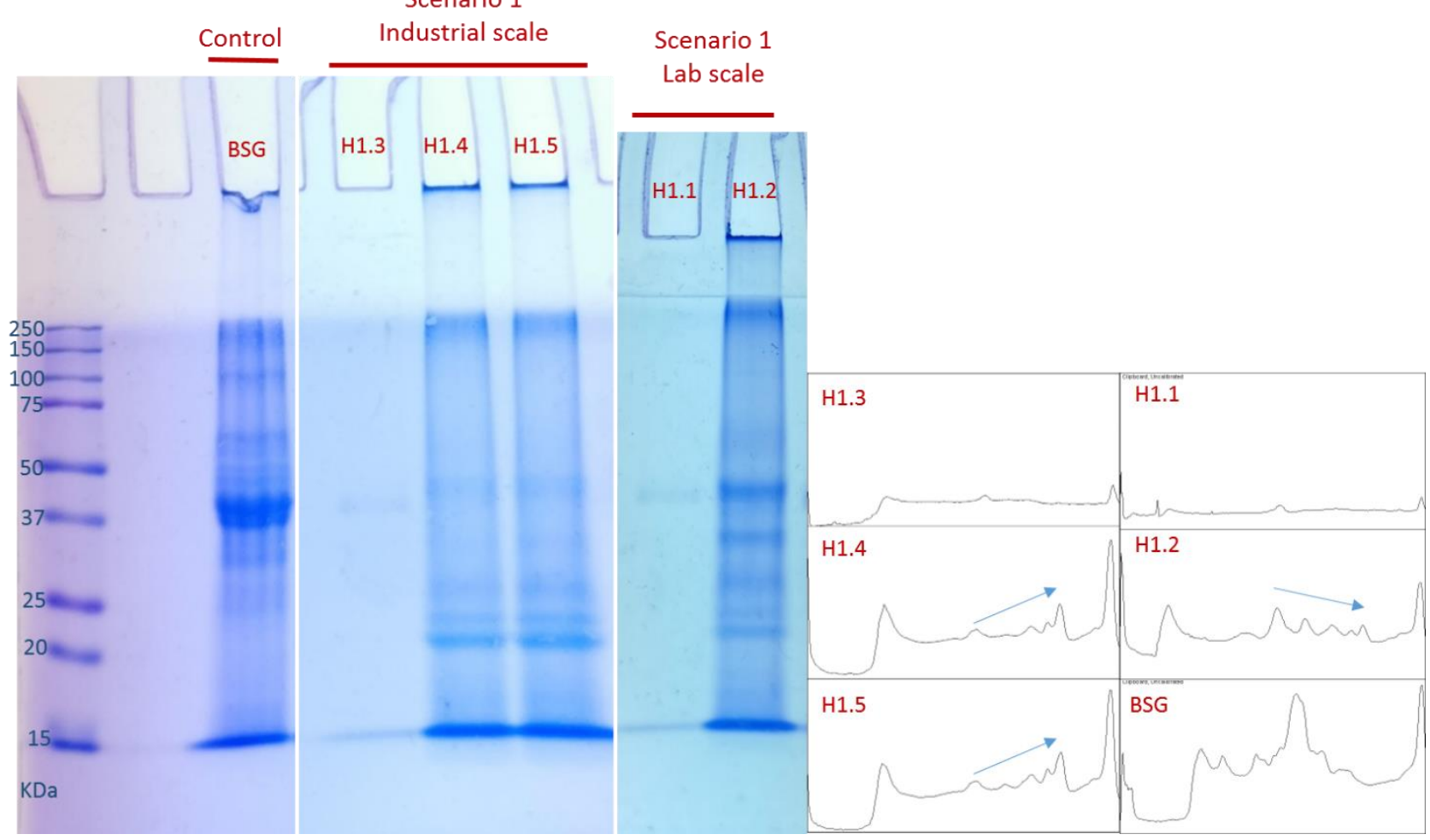

Fig. 6: Molecular profile distribution of the BSG hydrolysis scenario 1 at lab and industrial scale by SDS-PAGE method

\subsection{Determination of protein digestibility in fishes}

\subsubsection{Spent yeast}

No mortality was observed during the trial. The apparent digestibility coefficients (ADC) of the experimental diets formulated with spent yeast (BSY) and used for seabream are presented in Table 5. Digestibility of protein was high in all the diets $(71 \%-90 \%)$.

Table 5: Apparent Digestibility Coefficients (ACD) of BSY based experimental diets in gilthead seabream

\begin{tabular}{cccccccccc} 
Diet & \multicolumn{3}{c}{ Protein faeces } & \multicolumn{3}{c}{ Protein diet } & ADC & SD \\
\hline Control & 198.1 & \pm & 0.40 & 419.80 & \pm & 3.39 & 90.26 & 0.11 \\
D-Spent yeast 30 \% & 262.4 & \pm & 1.59 & 413.30 & \pm & 1.16 & 71.76 & 2.73 \\
H-Spent yeast 30\% & 223.1 & \pm & 2.79 & 418.20 & \pm & 2.49 & 75.01 & 1.27
\end{tabular}

The ADC of an ingredient reflects the capability of a certain species of fish to utilize its nutrients, predicting its potential as a feedstuff. In this case the results show acceptable digestibility of BSY for gilthead seabream indicating that BSY ingredients (protein but also lipids - not shown-) are suitable for aquaculture nutrition showing the hydrolysed prototypes a higher digestibility than non-hydrolysed.

\subsubsection{Spent grain}

The apparent digestibility coefficients (ADC) of the experimental diets formulated with spent grain (BSG) and used for gilthead seabream are shown in the Table 6. Digestibility of protein was high in all the diets (84-90\%)

Table 6: Apparent Digestibility Coefficients (ACD) of BSG based experimental diets in Gilt seabream

\begin{tabular}{cccccccccc} 
Diet & \multicolumn{3}{c}{ Protein faeces } & \multicolumn{2}{c}{ Protein diet } & ADC & SD \\
\hline Control & 198.1 & \pm & 0.40 & 419.80 & \pm & 3.39 & 90.26 & 0.11 \\
D-Spent grain 20\% & 118.2 & \pm & 3.41 & 417.70 & \pm & 3.51 & 84.01 & 0.54 \\
H-Spent grain 20\% & 87.8 & \pm & 0.90 & 392.80 & \pm & 0.70 & 85.22 & 0.31 \\
\hline
\end{tabular}


As in the case of BSY, the results of BSG can be considered acceptable for gilthead seabream ongrowing. Thus, brewers' spent grain (BSG) ingredients can be considered suitable for aquaculture nutrition. As in the case of BSY, hydrolysed prototypes have shown higher digestibility than non-hydrolysed.

In previous studies carried out with Mediterranean species like seabass (Metailler \& Huelvan, 1993; Campos et al, 2018) brewer's yeast have shown good digestibility results, much better when the product was previously hydrolysed and a peptide fraction higher than 3000 was used (Campos et al, 2018) giving values of 87.9 ADC.

\section{Conclusions}

The first conclusion is that the production of alternative ingredients for aquaculture feed based on brewers' by-products is feasible from the technical point of view. The enzymatic hydrolysis as pre-processing prior to dehydration has been demonstrated as an appropriate technique to increasing of the protein digestibility of ingredients, leading to a better intestinal absorption. Subsequently, the stabilization process consisted of a first mechanical dehydration, to reduce as much as possible the humidity (less than $60 \%$ ), and a second thermal drying, to reduce moisture content below $10 \%$, has been demonstrated appropriate for brewers'-based ingredient productions. Mechanical dewatering involves less energy demand and, therefore, a reduction of the energy necessary for thermal drying in the second step.

Moreover, brewers' by-products stand as a potential alternative for replacing fish meal in aquaculture feed due to their availability in Europe (over 40 billion litres of beer were produced in the European Union (EU) in 2018 [4]), their nutritional characteristics (high protein content), and the protein digestibility results obtained in the trials with fishes which have shown acceptable digestibility coefficients in the case of gilthead seabream (Sparus aurata) used as a model for Mediterranean aquaculture.

Finally, proposed solution involves an increase of the sustainability of aquaculture by providing two new, economically advantageous, protein sources that could replace fish meal. Thus, the reduction of aquaculture production costs will contribute to achieve the objectives established by the new European Common Fisheries Policy. In addition, the replacement of marine origin ingredients (fishmeal) will contribute to reduce significantly wild catches, contributing to achieve the goals defined in the Marine Strategy Framework Directive.

\section{Acknowledge}

Life BREWERY project (LIFE16ENV/ES/000160) is co-funded by LIFE European Environment Programme, which is the EU's financial instrument supporting environmental, nature conservation and climate action projects throughout the EU. The implementation, updating and development of EU environmental and climate policy and legislation by cofinancing projects with European added value are among its main priorities.

All the brewers by-products samples that have been used in this study have been provided by Mahou San - Miguel company (www.mahou-sanmiguel.com).

\section{References}

[1] FAO: The State of World Fisheries and Aquaculture 2018 - Meeting the sustainable development goals. FAO. http://www.fao.org/3/i9540en/i9540en.pdf (2018). Accessed 13 November 2019

[2] Bachis, E.: The Marine Ingredients Organization. Fishmeal and fish oil. A summary of global trends. $57^{\text {th }}$ IFFO Annual Conference. http://www.iffoevents.com/files/iffo/2.IFFO\%20Washington\%202017_1.pdf (2017). Accessed 13 November 2019

[3] Samuel-Fitwi, B., Meyer, S., Reckmann, K., Schroeder, J.P., Schulz, C.: Aspiring for environmentally conscious aquafeed: comparative LCA of aquafeed manufacturing using different protein sources. J. Clean. Prod. 52, 225-233 (2013)

[4] EUROSTAT: Happy International Beer Day! EUROSTAT. https://ec.europa.eu/eurostat/web/products-eurostatnews/-/EDN-20190802-1 (2019). Accessed 13 November 2019

[5] Rocha dos Santos, T., Fontes, V., Christe, M., Moretzsohn, P.P., Camporese, E.F.: Characterization and determination of brewer's solid wastes composition. J I Brewing (2015). https://doi.org/10.1002/jib.229|

[6] Mussatto, S.: Brewer's spent grain: A valuable feedstock for industrial applications. J Sci Food Agric (2014). https://doi.org/10.1002/jsfa.6486

[7] Fărcaş, A.C., Socaci, A.S., Mudura, E., Dulf, F.V., Vodnar, D.C., Tofană, M., Salanță, L.C.: Exploitation of Brewing Industry Wastes to Produce Functional Ingredients. In: Kanauchi, M. (ed) Brewing technologies, pp. 137-156. Intech open (2017)

[8] Hellborg, L., Piscur, J.: Yeast diversity in the brewing industry. In: Preddy, V.R. (ed) Beer in Health and Disease Prevention, pp. 1068-1073. New York, US: Elsevier (2009)

[9] Djuragic, O., Levic, J., Serdanovic, S.: Use of new feed from brewery by-products for breeding layers. Rom Biotech Lett. 15, 5559-5565 (2010) 
[10] Buffington, J.: The Economic Potential of Brewer's Spent Grain (BSG) as a Biomass Feedstock. Advances in Chemical Engineering and Science (2014). http://dx.doi.org/10.4236/aces.2014.43034

[11] Tang, Z., Cenkowski, S., Muir, W.E.: Modelling the superheated steam drying of a fixed bed of brewer's spent grain. Biosyst Eng. 87, 67-77 (2004). DOI: 10.1016/j.biosystemseng.2003.09.008

[12] Thiago, R., Pedro, P., Servulo, E.: Solid wastes in brewing process: A review. J. Brew. Distilling (2014). https://doi.org/10.5897/JBD2014.0043

[13] Kristinsson, H.G., Rasco, B.A.: Fish protein hydrolysates: Production, biochemical, and functional properties. Crit. Rev. Food Sci. Nutr. 40, 43-81 (2000)

[14] Friedman, M.: Nutritional Value of Proteins from Different Food Sources. A Review. J. Agric. Food Chem. 44, 629 (1996)

[15] Stone, D., Wilson, R., Wurtele, E.: Expanding the utilization of sustainable plant products in aquafeeds: A review. Aquac. Res. 38, 551-579 (2007)

[16] Ng, W.K., Gibon, V.: Fish oil replacement and alternative lipid sources in aquaculture feeds. In: Turchini, G.M., Ng, W.K., Tocher, D.R. (eds) Palm oil and Saturated Fatty Acid Rick Vegetable Oils., pp. 99-132. CRC Press, Taylor \& Francis Group (2012)

[17] Hou, H., Li, B., Zhao, X., Zhang, Z., Li, P.: Optimization of enzymatic hydrolysis of Alaska pollock frame for preparing protein hydrolysates with low-bitterness. LWT - Food Sci. Technol. (2011). https://doi.org/10.1016/j.lwt.2010.09.009

[18] Campos, I., Matos, E., Aragão, C., Pintado, M., Valente, L.: Apparent digestibility coefficients of processed agrofood by-products in European seabass (Dicentrarchus labrax) juveniles. Aquacult Nutr. 24 (4), 1274-1286 (2018)

[19] Ho, Y., Lin, C., Wu, M.C.: Evaluation of the prebiotic effects of citrus pectin hydrolysate. J. Food Drug Anal. 25, 550-558 (2017)

[20] Hou, Y., Wu, Z., Dai, Z., Wang, G., y Wu, G.: Protein hydrolysates in animal nutrition: Industrial production, bioactive peptides, and functional significance. J. Anim. Sci. Biotechnol. 8, (2017)

[21] Nitrogen Determination by the Kjeldahl Method

[22] Laemmli, U.: Cleavage of Structural Proteins during the Assembly of the Head of Bacteriophage T4. Nature. 227, 680-685 (1970). https://doi.org/10.1038/227680a0

[23] High Performance Liquid Chromatography (HPLC)

[24] George W., Latimer, J.R.: Official Methods of Analysis. 17 $7^{\text {th }}$ edition. The Association of Official Analytical Chemists AOAC. Gaithersbuig, Maryland, USA (2000)

[25] McCleary, B.V., Codd, R.: Measurement of (I-3) (I-4)- $\beta$-D-glucan in barley and oats: A streamlined enzymic procedure. J. Sci. Fd. Agric. 55, 303-312 (1991)

[26] Btitikofer, U., Fuchs, D., Bosset, J.O., Gmtir, W.: Automated HPLC-Amino Acid Determination of Protein Hydrolysates by Precolumn Derivatization with OPA and FMOC and Comparison with Classical Ion Exchange Chromatography. Chromatographia. 31, 441-447 (1991)

[27] Garantun-Tjeldsto, O., Ottera, H., Julshamn, K. \& Austrend, E.: Food ingestion in juvenile cod estimated by inert lanthanide markers -effects of food particle size. ICES J MAR SCI. 63, 311-319 (2006)

[28] Importance of savouriness in the acceptance of diets by fishes

[29] Sagar, V.R., Suresh Kumar, P.: Recent advances in drying and dehydration of fruits and vegetables: a review. J Food Sci Technol. 47, 15-26 (2009)

[30] Maynard, L.A., Loosli, J.K., Hintz, H.F.,Warner, R.G.: Animal nutrition. New York, NY: Mcgraw-Hill (1979)

[31] National Research Council: Nutrient Requirements of Fish and Shrimp. Washington, DC. The National Academies Press (2011). https://doi.org/10.17226/13039

Campos, I, Matos, E., Aragao, C., Pintado, M., Valente, L.M.P. Apparent digestibility coefficients of processed agrofood by-products in European sea bass (Dicentrarchus labrax) juveniles. Aquaculture Nutrition, 24, 1274-1286 (2018)_

Metailler, R., Huelvan, C. : Utilisation de levures dans l'alimentation du juvenile de bar (Dicentrarchus labrax). Fish Nutrition in Practice pp945-948. INRA, Paris, France (1993) 